\title{
Location, distribution, and quantification of myenteric plexus neurons of the jejunum of quails fed with different levels of commercial Macleaya cordata extract
}

\author{
Patrícia Franco Gonçalves Previato do Amaral $^{1^{*}(\mathbb{C})} \quad$ Wesley Alves Trindade ${ }^{1}$ (b) \\ Paula Montanhini Favetta ${ }^{1}$ Edson Gerônimo ${ }^{1}$ (i) $\quad$ Isabel Cristina da Silva Caetano ${ }^{1}$ (i) \\ Grazielli de Fatima Serenini ${ }^{1}$ (D) Gustavo Costardi Palin ${ }^{2}$ (D) Tatiana Kaori Urano ${ }^{2}$ (D) \\ Jean Marcos de Morais Oliveira ${ }^{2}$ (i) Lucas de Almeida Reati ${ }^{2}$ (i) Jaciele Caroline Pereira Dias $^{3}$ (D) \\ Luciana Kazue Otutumi ${ }^{1}$ (D) Andréia Assunção Soares ${ }^{1}$ (i) Ricardo de Melo Germano (D) $^{(\mathbb{D}}$
}

${ }^{1}$ Departamento de Pós-graduação em Ciência Animal com Ênfase em Produtos Bioativos, Universidade Paranaense (UNIPAR), 87502-210, Umuarama, PR, Brasil. E-mail: patriciapreviato@gmail.com. *Corresponding author. ${ }^{2}$ Médico Veterinário, Universidade Paranaense (UNIPAR), Umuarama, PR, Brasil. ${ }^{3}$ Departamento de Aquicultura e Desenvolvimento Sustentável, Universidade Federal do Paraná (UFPR), Palotina, PR, Brasil.

ABSTRACT: Coturniculture has been promising, progressing from a subsistence to a technical activity due to its quick production, low breeding investment, and rapid economic return. After the restriction of antimicrobials as growth promoters, some studies aimed to evaluate alternative products that would make the farming of healthy birds viable without impacting their performance, with commercial Macleaya cordata extract being one of these substitutes. The functions of the gastrointestinal tract are coordinated mainly by the enteric nervous system, and the myenteric plexus is responsible for the reflex control of contractile activities of the external muscles. Thus, this study located and demonstrated the distribution of the myenteric plexus, quantifing the total population of myenteric neurons (Giemsa+) and the subpopulation of myenteric nitrergic neurons (NADPH-d+), and evaluated the effects of commercial Macleaya cordata extract on these populations of quail jejunum neurons. A total of 240 one-day-old female laying quails were distributed into four treatments, with four repetitions of 15 birds each. The test groups $\left(T_{1}, T_{2}\right.$, and $\left.T_{3}\right)$ were treated with commercial Macleaya cordata extract throughout the experimental period using the following doses: 11 - test group, basal diet added with 150 ppm of the extract in the feed; $T_{2}$ - test group, basal diet added with100 ppm of the extract in the feed; T3 - test group, basal diet added with 50 ppm of the extract in the feed; and T4 - control group, basal diet with no added extract. The study included histological analysis, Giemsa+, and NADPH-d+ myenteric neuron staining. The results showed that the myenteric plexus is located between longitudinal layer fibers and in the transition region between the longitudinal and circular layers of the muscular tunic, with the myenteric population organized into ganglia and isolated in the region of neuronal fiber bundles. The commercial Macleaya cordata extract showed no quantitative changes in the myenteric Giemsa + population and myenteric NADPH-d + subpopulation, however, the groups that consumed the extract showed greater NADPH-d+ neuron activity compared to the control group, implying that the food remained longer in the intestinal lumen, therefore, enabling greater nutrient use and resulting in increased productive performance.

Key words: benzophenanthridine and protopine alkaloids, Coturnix coturnix japonica,enteric nervous system, Sangrovit.

Localização, distribuição e quantificação dos neurônios do plexo mioentérico do jejuno de codornas de postura alimentadas com diferentes inclusões do extrato comercial de Macleaya cordata

RESUMO: A coturnicultura tem apresentado características promissoras, deixando de ser uma atividade de subsistência e ocupando patamares tecnificados devido a sua precocidade produtiva, baixo investimento de criação e rápido retorno econômico. A partir da restrição da utilização de antimicrobianos como promotores de crescimento, estudos foram direcionados com o objetivo de se avaliar produtos alternativos que viabilizassem a criação de aves saudáveis, sem comprometer seu desempenho, sendo o extrato comercial da Macleaya cordata um destes substitutos. As funções do trato gastrintestinal são coordenadas principalmente pelo sistema nervoso entérico, sendo o plexo mioentérico responsável pelo controle reflexo das atividades contráteis da musculatura externa. Desta forma, o presente trabalho teve como objetivo localizar e demonstrar a distribuição do plexo mioentérico, quantificar a população total de neurônios mioentéricos (Giemsa+), e a subpopulação de neurônios mioentéricos nitrérgicos (NADPH-d+), além de avaliar os efeitos do extrato comercial da Macleaya cordata sobre estas populações de neurônios do jejuno de codornas. Foram alojadas 240 codornas de postura, fêmeas, com um dia de idade, distribuidas aleatoriamente em quatro tratamentos, com quatro repetições de 15 aves cada. Os grupos testes $\left(T_{1}, T_{2}\right.$ e $\left.T_{3}\right)$ foram tratados com extrato comercial de Macleaya cordata durante todo o periodo experimental conforme as doses indicadas, sendo: $T_{1}$ - grupo teste, com dieta basal adicionada de 150 ppm do extrato na ração; $T_{2}$ - grupo teste, com dieta basal adicionada de 100 ppm do extrato na ração; $T_{3}$ - grupo teste, com dieta basal adicionada de 50 ppm do extrato na ração, e $T_{4}$ - grupo controle, com dieta basal isenta do extrato. Foram realizadas análise histológica e a marcação dos neurônios mioentéricos Giemsa + e NADPH-d+. Os resultados demonstraram que o plexo mioentérico está localizado entre as fibras do estrato longitudinal, e na região de transição entre os estratos longitudinal e circular da túnica muscular, estando a população mioentérica organizada em gânglios, e também isoladamente na região dos feixes das fibras neuronais. O extrato comercial da Macleaya cordata não alterou quantitativamente os neurônios da população mioentérica Giemsa+e da subpopulação mioentérica NADPH-d+, mas os grupos que consumiram o extrato apresentaram maior atividade dos neurônios NADPH- $d+$ em relação ao grupo controle, permitindo inferir que o alimento permaneceu maior tempo no lúmen intestinal e, portanto, possibilitou um maior aproveitamento dos nutrientes, podendo refletir em melhor desempenho produtivo. Palavras-chave: alcaloides da benzofenantridina e protopina, Coturnix coturnix japonica. Sangrovit, sistema nervoso entérico. 


\section{INTRODUCTION}

Coturniculture is the segment of the poultry industry responsible for raising, promoting, and managing quails (SILVA et al., 2018), standing out from its modernization, followed by new production technologies, progressing from a subsistence to a technical activity, with positive results to investors (PASTORE et al., 2012).

Besides favorable results, coturniculture has encouraging characteristics such as low initial investment and fast economic return, with quails being fast-growing birds with good feed conversion, early sexual maturity ( 35 to 42 days), and productive longevity (14 and 18 months), which requires small farming spaces (MURAKAMI \& ARIKI, 1998; PASTORE et al., 2012). In this context, quail farming plays an important social role, providing a source of income for family agriculture and small rural producers (SILVA et al., 2018).

In the development and modernization of coturniculture, associated with the current restriction on the use of antimicrobials as growth promoters in animal nutrition, some studies aimed to evaluate alternative products to replace growth promoters in animal feed without decreasing productivity and enabling the rearing of healthy birds (BONATO et al., 2008; OTUTUMI et al., 2009) and safety food for the consumer, eliminating the possibility of residues and bacterial resistance.

According to KANTAS et al. (2015), Macleaya cordata extract meets the requirement for animal production free of antibiotics and growth promoters, increasing performance and profitability. SANGROVIT ${ }^{\circledR} E D$ is a natural product made from plants of the family Papaveraceae, which contains $1 \%$ Macleaya cordata extract in its composition (SANGROVIT ${ }^{\circledR}$ ED, 2019).

High bird productivity depends on adequate nutrients for the body. For nutrients to be digested and absorbed, the intestinal mucosa needs satisfactory morphophysiological structures, since digestion depends on mechanisms occurring in the intestinal wall, with its preservation and integrity being of vital importance (PATRÍCIO, 2016).

Gastrointestinal functions are coordinated mainly by intrinsic neurons of the enteric nervous system (ENS), besides the participation of autonomic extrinsic neurons of the sympathetic and parasympathetic pathways and sensory neurons (BAYLISS \& STARLING, 1899; FRAUCHES et al., 2016; HANSEN, 2003; LANGLEY, 1921).

The ENS is organized in the form of plexuses, composed of numerous ganglia of various sizes along its extension, with a greater concentration of intestinal nervous cells arranged into two sets of ganglia. The ganglia of the myenteric plexus are responsible for controlling the reflex of contractile activities of the external musculature, while the ganglia of the submucous plexus are responsible for coordinating secretomotor and vasomotor activities of the mucous tunic (FRAUCHES et al, 2016; FURNESS, 2006; SCHEMANN, 2005).

The myenteric plexus is described as a nerve network with small ganglia (FURNESS, 2006) arranged along the gastrointestinal tract from the esophagus to the rectum, located between the circular and longitudinal layers of the muscular tunic (FRAUCHES et al, 2016; FURNESS \& COSTA, 1980; FURNESS, 2006; HANSEN, 2003), with neuron organization and density varying with animal species and the segment of the digestive tract being studied (GABELLA, 1981; IRWIN, 1931) and presenting an easily identifiable mesh format (GABELLA, 1981).

FRAUCHES et al. (2016) and HANSEN (2003) reported that enteric neurons express different neurotransmitters that define their neuronal function. FURNESS (2000), FURNESS (2006), and TAKEUCHI et al. (2005) reported that acetylcholine is the main excitatory neurotransmitter in smooth muscles of the digestive tract that acts through $\mathrm{M}_{2}$ muscle receptors (TAKEUCHI et al., 2005), presenting the substance $P$ as co-transmitter (FURNESS, 2006). In addition, FURNESS (2000) and FURNESS (2006) described that nitric oxide (NO) is an inhibitory neurotransmitter synthesized when necessary from the activation of the enzyme nitric oxide synthase (NOS), present in inhibitory enteric neurons, which, according to BROOKES (1993), promotes the relaxation of gastrointestinal smooth muscles.

This study was conceived considering the properties of Macleaya cordata extract as an alternative feed additive for production animals, due to the growing interest in coturniculture, the scarcity of morphophysiological studies on the myenteric plexus of quails, and the lack of studies on the effects of Macleaya cordata extract on the myenteric plexus of quail, this study aimed to locate the myenteric plexus, demonstrating its distribution in this plexus, quantifing the total population of myenteric neurons (Giemsa + ) and the subpopulation of myenteric nitrergic neurons (NADPH-d + ), and evaluating the effects of Macleaya cordata extract on these populations of laying quail jejunum neurons.

Ciência Rural, v.51, n.11, 2021. 


\section{MATERIALS AND METHODS}

This study was evaluated and approved by the Committee on Animal Research and Ethics (CARE) of the Paranaense University (UNIPAR) under protocol number 31660/2017.

\section{Animals, treatment, and environment}

The experiment was conducted in the Experimental Aviary, UNIPAR Campus II, with 240 one-day-old female laying quails (Coturnix coturnix japonica) with a mean weight of $6.31 \mathrm{~g}$, from the Vicami Codornas, Assis, SP, being randomly distributed into four treatments, with four repetitions of 15 birds each. The test groups $\left(\mathrm{T}_{1}, \mathrm{~T}_{2}\right.$ and $\left.\mathrm{T}_{3}\right)$ were treated with commercial Macleaya cordata extract through out the experimental period using the following doses: T1 - test group, basal diet added with $150 \mathrm{ppm}$ of the extract in the feed; $\mathrm{T}_{2}$ - test group, basal diet added with $100 \mathrm{ppm}$ of the extract in the feed; T3 - test group, basal diet added with 50 ppm of the extract in the feed; and T4 - control group, basal diet with no added extract. The quails of 1 to 35 days of age were kept in boxes with bedding at an ideal comfort temperature for their age, with $a d$ libitum water and balanced feed (ROSTAGNO et al., 2017)without the addition of anticoccidials or growth promoters produced in the Laboratory of Animal Nutrition, UNIPAR Campus II.

Commercial Macleaya cordata Extract - Sangrovit ${ }^{\circledR}$ ED

Sangrovit ${ }^{\circledR}$ ED is a feed additive consisting of the extract of the Macleaya cordata plant at $1 \%$ concentration having benzophenanthridine (sanguinarine and chelerythrine) and protopine (protopine and allocryptopine) alkaloids as bioactive compounds, which improve intestinal integrity at a dosage of 50 to $150 \mathrm{ppm}$ in the feed (50 to $150 \mathrm{~g} / \mathrm{ton}$ ).

Euthanasia of the animals and jejunum fragment collection

After the 35-day trial period at the Experimental Morphology Laboratory of the Graduate Program in Animal Science with Emphasis on Bioactive Products, UNIPAR central campus, one quail per repetition was randomly selected to be euthanized, totaling four birds per group, using an anesthetic protocol with xylazine hydrochloride as pre-anesthetic medication at an intramuscular dosage of $4 \mathrm{mg} / \mathrm{kg}$, and sodium thiopental as anesthetic at an intramuscular dosage of $25 \mathrm{mg} / \mathrm{kg}$.

Subsequently, the birds were necropsied and three jejunum fragments were collected 2 $\mathrm{cm}$ anteriorly to the yolk diverticulum (Meckel's diverticulum). The first segment was used for Giemsa positive myenteric neuronstaining (Giemsa + ).The second fragment was used to detect NADPH positive myenteric neurons (NADPH-diaphorase), which respond to the neurotransmitter NO, also called nitrergic neurons. Lastly, the third fragment was used to locate the myenteric plexus using the hematoxylineosin (HE) technique.

Giemsa + myenteric neuron staining: evidence of total neuronal population, according to BARBOSA (1978)

To stain the Giemsa+ myenteric neurons, fragments of the jejunum of each bird were washed with $0.9 \%$ saline solution. The oral and aboral ends were sutured with cotton thread, and the interior was filled with Giemsa fixative solution, being immersed in the same solution until membrane preparations were obtained. Each membrane preparation was then placed in a Giemsa staining solution containing methylene blue in Sorensen phosphate buffer $(\mathrm{pH}$ 6.9) for 24 hours at room temperature. Moreover, the membrane preparations were dehydrated in an alcohol sequence (95\%, Absolute I, Absolute II) and were diaphanized with two consecutive Xylol immersions (Xylol I and II, for five minutes each). Each membrane preparation was placed on a slide and coverslipped with synthetic resin.

\section{Obtaining membrane preparations}

After the fixation period, the jejunum sutures were removed, and the segment was sectioned transversely to obtain a fragment of approximately $8 \mathrm{~mm}$ in width. The fragment was then sectioned along the longitudinal axis of the mesenteric border and micro-dissected in a glass plate using a transilluminated stereomicroscope forceps, removing the mucous and submucous coats and preserving the muscular and serosal.

Myenteric nitrergic neurons detection (NADPH-d+): evidence of nitrergic neuronal subpopulation, according to SCHERER-SINGLER et al. (1983)

To detect myenteric nitrergic neurons (NADPH- + ), fragments of the jejunum of each bird were washed with sodium phosphate buffer solution (PBS) ( $\mathrm{pH} 7.4$ ), sutured at the oral and aboral ends with cotton thread, and had their interior filled with the same solution, being subsequently immersed in $4 \%$ paraformaldehyde for 30 minutes and then washed in PBS containing Triton X-100 at $0.3 \%$ for ten minutes. The jejunum fragments were then washed again in PBS three times (ten minutes each) and incubated for 
90 minutes in a reaction medium containing $50 \mathrm{mg}$ Nitro Blue Tetrazolium (NBT), $100 \mathrm{mg} \beta-\mathrm{NADPH}$, and $0.3 \%$ Triton $\mathrm{X}-100$ in Tris- $\mathrm{HCl}$ buffer $(0.1 \mathrm{M}$, $\mathrm{pH}$ 7.6). After this, the jejunum fragments were again washed in PBS for three more times (five minutes each), and at the end of this period, the fragments were removed and were immersed in $4 \%$ paraformaldehyde solution to interrupt the reaction, and for fixation and storage, obtaining membrane preparations as previously described. Subsequently, the membrane preparations were dehydrated in an increasing alcohol sequence $(80 \%, 90 \%$, Absolute I, and Absolute II), followed by diaphanization in Xylol (I and II), and placed on aslide and coverslippedwith synthetic resin.

Quantification of neurons evidenced by the Giemsa and NADPH-d histochemistry techniques

The model proposed by SANT'ANA et al. (1997) was used to guide the uniform capture of mesenteric, intermediate, and anti-mesenteric images. Under light microscopy (Nikon Eclipse E200), the material obtained was visualized with a 40x objective and the images were transferred from the microscope to a computer using an image analysis system coupled with a high-resolution photographic camera (Moticam 5.0 megapixels), with 120 random microscopic fields being captured per membrane preparation. In addition, the images of mesenteric, intermediate, and antimesenteric areas of the jejunum were quantitatively analyzed for myenteric neurons stainedby the Giemsa and NADPH-d histochemistry techniques, with the neuron mediums being considered in alternate fields.

\section{Statistical analysis}

The data was subjected to descriptive analysis using the BioEstat 5.0 software (AYRES et al., 2007). The normality was evaluated (Lilliefors). The data regarding the NADPH-d+ neuron count showed normal distribution, which was compared using analysis of variance (ANOVA). The data on Giemsa+ neuron counts were not normally distributed, which were compared using the Kruskal-Wallis test. A 5\% significance level was considered for all data.

\section{RESULTS AND DISCUSSION}

The myenteric population (Giemsa + ) and the nitrergic subpopulation (NADPH-d+) of the myenteric plexus of laying quails (Coturnix coturnix japonica) fed with different levels of commercial Macleaya cordata extract were evaluated.
The histological sections showed that the myenteric plexus is located between the fibers of the longitudinal layer and in the transition between the fibers of the longitudinal and circular layers of the muscular tunic of the jejunum (Figure 1). FRAUCHES et al. (2016), FURNESS (2006), and HANSEN (2003), reported that the myenteric plexus is in this position from the esophagus to the rectum, and LI et al. (1994) reported that it is in the small intestine of broiler quails (Coturnix coturnix coturnix).

The myenteric Giemsat population and the NADPH-d+ neuron subpopulation were arranged in ganglia, which were isolated between the neuronal fibers that establish communication between the ganglia (Figure 2). LI et al. (1994) verified in the european quail gizzards, however, data regarding their distribution in the jejunum was not found. PREVIATO DO AMARAL et al. (2017) studied NADPH-d+ neurons in the duodenum of broiler chickens (Gallus gallus domesticus) aged 21 days; they reported neurons in separated ganglionic arrangements between the fibers that interconnect the ganglia. YANG et al. (2013) analyzed the distribution of myenteric neurons in the ileum of chickens ageing 65 days, also reporting the same distribution. Thus, even analyzing other bird species, the studies cited supported the results of the present study.

There was no difference between the test $\left(\mathrm{T}_{1}, \mathrm{~T}_{2}\right.$, and $\left.\mathrm{T}_{3}\right)$ and control groups (T4) regarding the density of the Giemsa+ myenteric neuron population and NADPH-d+ myenteric neuron subpopulation (Table 1), demonstrating that the commercial Macleaya cordata extract did not interfere with the myenteric neuronal density of the jejunum of laying quails. The area corresponding to the 120 microscopic fields sampled for each jejunum fragment was 7.2 $\mathrm{mm}^{2}$, being later standardized in $\mathrm{mm}^{2}$.

This study was descriptive and exploratory since no studies have reported myenteric neuronal density and distribution in laying quails (Coturnix coturnix japonica) or the effects of commercial Macleaya cordata extract on the population of myenteric neurons of any species.

The density of nitrergic neurons reported in the control group was $40.3 \pm 8.0$ neurons $/ \mathrm{mm}^{2}$; however, LI et al. (1994) reported a density of $208 \pm 21$ NADPH- $\mathrm{d}+/ \mathrm{mm}^{2}$ neurons in the small intestine of European quails. It should be noted that the density of myenteric nitrergic neurons does not correspond only to morphological adaptations and eating habits (STABILLE et al, 2002), but also to the metabolic state of the animal at the time of neuron staining. According to SCHERER-SINGLER et al. (1983), a 


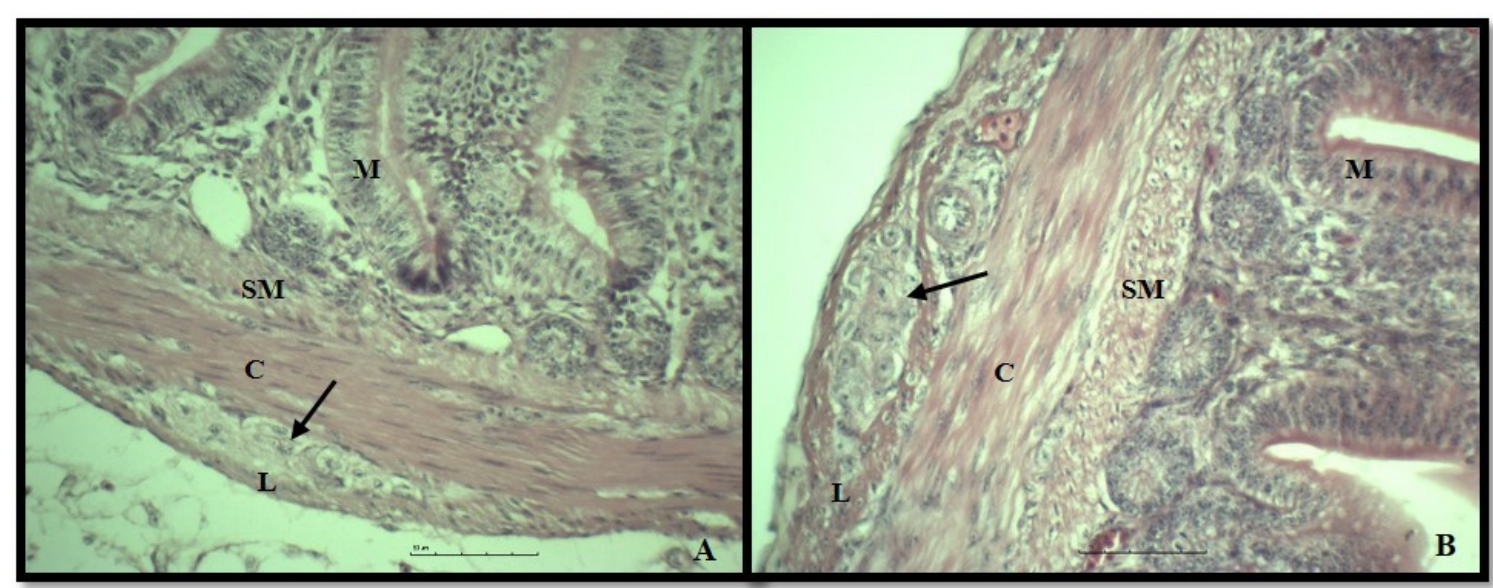

Figure 1 - Photomicrograph of transversal sections of the jejunum of laying quails stained by the HE technique, showing the mucosal (M), submucosal (SM), and muscular layers divided into the circular (C) and longitudinal (L) layer. The arrow in A shows the myenteric plexus ganglion located in the transition of the longitudinal and circular layers of the muscular layer, and the arrow in B shows the myenteric plexus between the fibers of the longitudinal layer of the muscular layer. $(50 \mu \mathrm{m}$ bar, $40 \mathrm{x}$ magnification).

Source: Personal file.

lower number of nitrergic neurons does not necessarily indicate a lower number of existing nitrergic neurons in the animal, because only the active neurons are demonstrated with the technique used.

Studies on other bird species, such as the one by PREVIATO DO AMARAL et al. (2017), found a density of $24.38 \pm 4.97$ NADPH-d $+/ \mathrm{mm}^{2}$ neurons in the duodenum of broiler chickens aged 21 days. YANG et al. (2013) reported 45.92 \pm 17.51 NADPH- $\mathrm{d}+/ \mathrm{mm}^{2}$ neurons in the jejunum of broiler chickens aged 40 days. These authors suggested that smaller animals may present higher neuronal density of the myenteric plexus. However, the present study showed lower myenteric nitrergic density than YANG et al. (2013) in broiler chickens; however, a higher density was reported by PREVIATO DO AMARAL et al. (2017).

SERENINI (2020) emphasized that the quantitative variations in neurons of the myenteric plexus should consider intra-species differences, such as animals of different ages, different intestinal regions studied, as well as the region of the sampled organ. In addition, interspecific differences must also be evaluated, such as the feeding habit of the species, its body mass, and the regions of intestinal fragment collection.

To stain the total myenteric neuron population, the present study used the Giemsa technique, with no significant differences between treatments, as well as with the control group (Table 1). According to BARBOSA (1978), the Giemsa staining technique, which uses the methylene blue dye in digestive tract membrane preparations, can be used as one of the available methods to evaluate the total myenteric neuronal population due to the affinity of the dye for acid structures in nerve cells (SANT'ANA et al., 2012).GÓIS et al. (2016) reported that the polyribosomes of all neurons can be stained by the Giemsa technique.

It should be noted that this staining aimed to evaluate the nitrergic subpopulation in relation to the total number of myenteric neurons in the jejunum of quails, estimating the number of active neurons in this subpopulation under the research conditions.

The mean NADPH-d+ neurons showed in groups $\mathrm{T}_{1}, \mathrm{~T}_{2}, \mathrm{~T}_{3}$, and $\mathrm{T}_{4}$ corresponded to $26.72 \%$, $23.66 \%, 26.36 \%$, and $17.79 \%$ of the population of Giemsa+ myenteric neurons, respectively. According to LI et al. (1994), nitrergic neurons comprised one third of the myenteric neurons in each sampled region of the gastrointestinal tract of European quails. Several studies with different animal species reported similar results, such as SERENINI (2020), with $20.4 \%$ active NADPH-d+ neurons in the jejunum of bats, FEREZIN et al. (2017), with approximately $26.0 \%$ NADPH-d+ neurons in the colon of Wistar

Ciência Rural, v.51, n.11, 2021. 


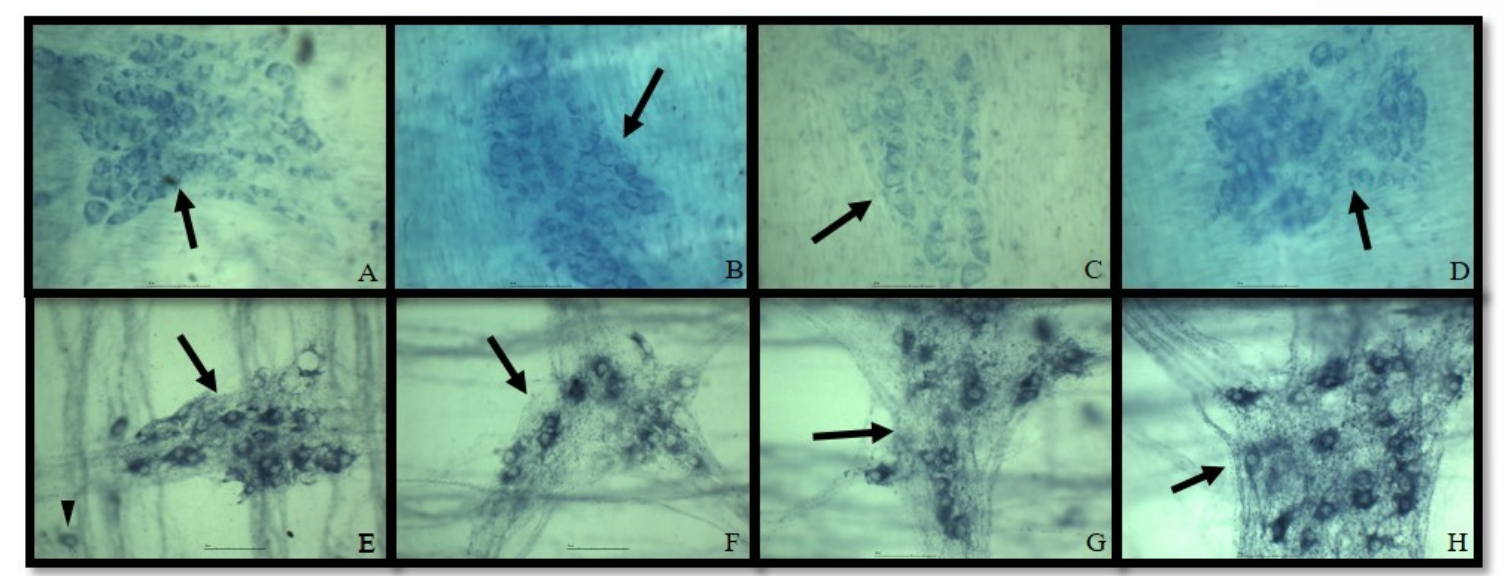

Figure 2 - Photomicrograph of the jejunum of laying quails in the treatment $\left(T_{1}\right.$ to $\left.T_{3}\right)$ and control $\left(T_{4}\right)$ groups stained by the Giemsa method (A to D) and by NADPH-diaphorase histochemistry (E to $\mathrm{H}$ ), showing the ganglionic arrangement of the myenteric plexus (arrow) and the presence of isolated neurons between the neuronal fibers that connect the ganglia (arrow head). (50 $\mu \mathrm{m}$ bar, $40 \mathrm{x}$ magnification).

Source: Personal file.

rats, FURNESS (2006), with 23.0\% NADPH-d+ neurons in the small intestine of guinea pigs, and QU et al. (2008), with $29.0 \%$ NADPH-d+ neurons in the ileum of mice.

As NO is an extremely specific neurotransmitter produced when the NOS enzyme is activated (FURNESS, 2006), it is possible to infer that a lower nitrergic activity, as observed in the control group, increases the speed of food transit, therefore reducing its time in the intestinal lumen, consequently decreasing nutrient use and increasing food conversion (Table 2). SANDERS \& WARD (1992) studied the colon of guinea pig neck and verified that NO promoted relaxation of the intestinal smooth muscle, allowing greater absorption capacity,resulting in greater fluid and electrolyte absorption (MIZUTA et al., 1999).

The bioactive compounds of Macleaya cordata extract include quaternary benzophenanthridine (sanguinarine and chelerythrine) (KOSINA et al., 2004; OLIVEIRA, 2012; SANGROVIT $^{\circledR}$ ED, 2019; SIMANEK et

Table 1 - Density of my enteric neurons revealed by the Giemsa a method (A to D) and by NADPH-diaphorase histochemistry, corresponding to $1.00 \mathrm{~mm}^{2}$ of the jejunum of laying 35-day-old quails fed with different levels of commercial Macleaya cordata extract.

\begin{tabular}{|c|c|c|c|c|}
\hline \multirow[b]{2}{*}{ Treatments } & \multicolumn{2}{|c|}{ 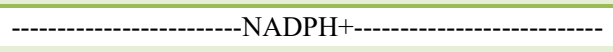 } & \multicolumn{2}{|c|}{ 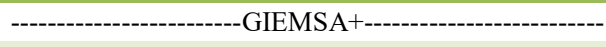 } \\
\hline & Mean & $\mathrm{CV} \%$ & Mean & $\mathrm{CV} \%$ \\
\hline $\mathrm{T}^{1}-150 \mathrm{ppm}$ & 42.3 & 27.76 & 158.3 & 11.03 \\
\hline $\mathrm{T}_{2}-100 \mathrm{ppm}$ & 34.5 & 13.90 & 145.8 & 32.28 \\
\hline $\mathrm{T}^{3}-50 \mathrm{ppm}$ & 42.3 & 31.54 & 160.5 & 23.16 \\
\hline $\mathrm{T}^{4}-$ Control & 40.3 & 39.62 & 226.5 & 14.87 \\
\hline SEM & \multicolumn{2}{|c|}{----------------------------------5.75----------------------------- } & \multicolumn{2}{|c|}{----------------------------------16.90---------------------------- } \\
\hline P-value & \multicolumn{2}{|c|}{ 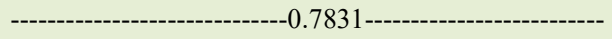 } & ------------------. & -------------------- \\
\hline
\end{tabular}

CV\%: Coefficient of variation; SEM: Standard error of mean. 
Table 2 - Mean weight gain (g) and feed conversion of one-to-35-day-old laying quails fed with different levels of commercial Macleaya cordata extract.

\begin{tabular}{lcc}
\hline Treatments & Weight gain $(\mathrm{g})$ & Food conversion $(\mathrm{g} / \mathrm{g})$ \\
\hline $\mathrm{T}^{1}-150 \mathrm{ppm}$ & 128.17 & $3.068 \mathrm{ab}$ \\
$\mathrm{T}_{2}-100 \mathrm{ppm}$ & 126.32 & $2.912 \mathrm{~b}$ \\
$\mathrm{~T}^{3}-50 \mathrm{ppm}$ & 125.47 & $3.140 \mathrm{ab}$ \\
$\mathrm{T}^{4}-$ Control & 124.82 & $3.183 \mathrm{a}$ \\
$\mathrm{SEM}$ & 1.67 & 0.05 \\
P-value & 0.6483 & $0.0365^{*}$ \\
$\mathrm{CV} \%$ & 2.66 & 3.24 \\
\hline
\end{tabular}

*Means followed by different letters differ by the Tukey'stest. $\mathrm{CV} \%$ : Coefficient of variation; SEM: Standard error of mean.

al., 2003) and protopinealkaloids (protopine and allocryptopine)(KOSINA et al, 2004; OLIVEIRA, 2012; $\quad$ SANGROVIT $^{\circledR}$ ED, 2019); phenolic acids (gallic, protocatechuic, p-hydroxybenzoic, m-hydroxybenzoic, gentisic, p-coumaric, caffeic, ferulic, and sinapinic acids); and fatty acids (linoleic, oleic, palmitic and stearic acids) (KOSINA et al., 2004).

Sanguinarine and chelerythrine alkaloids have antimicrobial (KOSINA et al., 2004; LIU et al., 2016; SIMANEK et al., 2003), antiinflammatory (KANTAS et al., 2015; KHADEM et al., 2014; KOSINA et al., 2004, LIU et al., 2016; SANGROVIT $^{\circledR}$ ED, 2019; SIMANEK et al., 2003), immunomodulatory (SIMANEK et al., 2003; ZDAŘILOVÁ et al., 2006), and local anesthetic effects (KOSINA et al., 2004; SIMANEK et al., 2003). According to BAE et al. (2012),protopine is an isoquinoline alkaloid that minimizes the inflammatory process by inhibiting lipopolysaccharides due to a reduced inflammatory response, as well as inhibiting the cyclooxygenase-2 (COX-2) enzyme and $\mathrm{E}_{2}$ prostaglandin, without cytotoxic effects and decreasing pro-inflammatory cytokines.

In this study, health challenges that could affect the gastrointestinal system and evidence of inflammatory or infectious processes were not found. However, the compounds present in Macleaya cordata extract included antioxidants, which have a potential neuroprotective effect. No studies on the effect of this extract on the myenteric plexus were reported in the literature; however, other antioxidant compounds such as ascorbic acid (CLEBIS et al., 2013) and quercetin (FERREIRA et al., 2011) had the mentioned effect.

Myenteric neurons receive their nutrition by diffusion from blood vessels reported in the surrounding connective tissue (GABELLA, 1987). According to FURNESS (2006), there is no effective blood/neuron barrier, i.e., drugs can affect the ENS. Events that may damage or produce functional neuronal changes require adaptations, as well as an additional effort to ensure neuronal viability (EKBLAD \& BAUER, 2004). Under our experimental conditions, the nitrergic neurons proved to be more adapted to different levels of Macleaya cordata extract in the diet of laying quails.

\section{CONCLUSION}

The myenteric plexus is located between longitudinal layer fibers and longitudinal and circular layers of the muscular tunic, similar to the other species studied. Furthermore, the myenteric population is mostly organized in ganglia, however, it is isolated between the neuronal fibers that establish the communication between the ganglia.

Under this experiment conditions, the commercial Macleaya cordata extract showed no quantitative neuron changes in the myenteric Giemsa+ population and myenteric NADPH-d+ subpopulation, however, the groups that consumed the extract showed greater NADPH-d+ neuron activity compared to the control group, implying that the food remained longer in the intestinal lumen, which can indicate greater nutrient use, resulting in increased performance.

The study of the myenteric Giemsa+ population and NADPH-d+ subpopulation and the effects of the commercial Macleaya cordata extract on these neurons improve knowledge on the functionality of the ENS in digestive processes, serving as a reference for future research in the poultry industry.

Ciência Rural, v.51, n.11, 2021. 


\section{ACKNOWLEDGMENTS}

The authors thank the UNIPAR Executive Board of Research Management and Graduate Program (DEGPP) for the financial support for the development of this research, Phytobiotics Brazil for donating the commercial extract used in this experiment, and Vicami Codornas for donating the quails. They also thank the Araucaria Foundation for Scientific and Technological Development of the State of Paraná (public notice 09/2016) for financial support, and the support of the Coordination for the Improvement of Higher Level Personnel - Brazil (CAPES).

\section{BIOETHICS AND BIOSSECURITY COMMITTEE APPROVAL}

This research was conducted in accordance with the norms edited by the National Council for the Control of Animal Experimentation (CONCEA) and was approved by the CARE of UNIPAR, under protocol No. 31660/2017.

\section{DECLARATION OF CONFLICT OF} INTEREST

The authors declare no conflicts of interest. This article is part of the $\mathrm{PhD}$ dissertation of the first author in the Graduate Program in Animal Science with Emphasis on Bioactive Products at UNIPAR, Umuarama, Paraná, Brazil.

\section{AUTHORS' CONTRIBUTIONS}

All authors contributed equally for the conception and writing of the manuscript. All authors critically revised the manuscript and approved of the final.

\section{REFERENCES}

AYRES, M. et al. BioEstat 5.0: Aplicações Estatísticas nas Áreas das Ciências Biológicas e Médicas. Belém: Sociedade Civil Mamirauá, MCT-CNPq, 2007. 364 p.

BAE, D. S. et al. Protopine reduces the inflammatory activity of lipopolysaccharide-stimulated murine macrophages. BMB Reports, v.45, n.2, p.108 -113, 2012. Available from: <http:// koreascience.or.kr/article/JAKO201208636393961.pdf >. Accessed: Jul. 15, 2019. doi: 10.5483/bmbrep.2012.45.2.108.

BARBOSA, A. J. A. Técnica histológica para gânglios nervosos intramurais em preparados espessos. Brazilian Journal of Medical and Biological Research, v.11, p.95-97, 1978. Available from: $<$ http://pascal-francis.inist.fr/vibad/index. php? action $=$ getRecordDetail\&idt $=$ PASCAL 7950158800> . Accessed: Jul. 15, 2019.

BAYLISS, W. M.; STARLING, E. H. The movements and innervation of the small intestine. The Journal of Physiology, v.24, n.2, p.99-143, 1899. Available from: <https://www.ncbi.nlm. nih.gov/pmc/articles/PMC1516636/pdf/jphysio102595-0001.pdf>. Accessed: Jul. 15, 2019. doi: 10.1113/jphysiol.1899.sp000752.

BONATO, M. A. et al. Effect of Organic Acid and Plant Extract on Performance and Quality Egg Of Laying Hens. Ars Veterinaria, v.24, n.3, p.186-192, 2008. Available from: <http://www. arsveterinaria.org.br/ars/article/view/198/161>. Accessed: Jul. 15, 2019. doi: 10.15361/2175-0106.2008v24n3p186-192.

BROOKES, S. J. H. Neuronal nitric oxide in the gut. Journal of Gastroenterology and Hepatology, v.8, n.6, p.590- 603, 1993. Available from: <https://onlinelibrary.wiley.com/doi/ pdf/10.1111/j.1440-1746.1993.tb01658.x>. Accessed: Jul. 15, 2019. doi: 10.1111/j.1440-1746.1993.tb01658.x.

CLEBIS, N. K. et al. Effects of ascorbic acid supplementation on myenteric neurons in the stomach of diabetic rats. Arquivos de Ciências da Saúde da UNIPAR, v.17, n.3, p.175-181, 2013. Available from: <https://www.revistas.unipar.br/index.php/saude/ article/view/5068/2950>. Accessed: Jul. 15, 2019. doi: 10.25110/ arqsaude.v17i3.2013.5068.

EKBLAD, A. E.; BAUER, A. J. Role of vasoactive intestinal peptide and inflammatory mediators in enteric neuronal plasticity. Neurogastroenterology and Motility, v.16, n.1, p124-128. 2004. Available from: $<$ https://onlinelibrary.wiley.com/doi/epdf/10.1 111/j.1743-3150.2004.00487.x>. Accessed: Jul. 15, 2019. doi: 10.1111/j.1743-3150.2004.00487.x.

FEREZIN, R. I. et al. Different inoculum loads of Toxoplasma gondii induce reduction of myenteric neurons of the rat colon. Brazilian Journal of Veterinary Parasitology, v.26, n.1, p.4753, 2017. Available from: <https://www.scielo.br/pdf/rbpv/ v26n1/1984-2961-rbpv-26-1-47.pdf>. Accessed: Jul. 15, 2019. doi: $10.1590 / \mathrm{s} 1984-29612017003$.

FERREIRA, P. E. B. et al. Estudo do efeito da quercetina sobre neurônios da população total e células gliais do plexo mioentérico do ceco de ratos diabéticos. Maringá, 23 ago. 2011. Available from: <http://www.mudi.uem.br/spne/images/stories/ resumos/Diabetes/A9.pdf>. Accessed: Jul. 15, 2019.

FRAUCHES, A. B. et al. O sistema nervoso entérico. In: ORIÁ, R. B.; BRITO, G.A.C. Sistema digestório: integração básico-clínica. São Paulo: Edgard Blucher, 2016. p.315-333.

FURNESS, J. B.; COSTA, M. Types of nerves in the enteric nervous system. Neuroscience, v.5, p.1-20, 1980. Available from: $<$ https://www. sciencedirect.com/science/article/pii/B9780080255019500168>. Accessed: Jul. 15, 2019. doi: 10.1016/B978-0-08-0255019.50016-8.

FURNESS, J. B. Types of neurons in the enteric nervous system. Journal of the Autonomic Nervous System, v.81, p.87-96, 2000. Available from: $<$ https://reader.elsevier.com/reader/sd/pii/S01651 83800001272 ? token $=020802863$ D1C7CD2D57BD26105FF663D C1CB96F6C3DB6BC5E68C61E8EED12FA0C03A53197003B3 9F0210D5285D0B2238>. Accessed: Jul. 15, 2019. doi: 10.1016/ S0165-1838(00)00127-2.

FURNESS, J. B. The enteric nervous system. Massachusetts: Blackwell Publishing, 2006. 274p.

GABELLA, G. Structure of muscles and nerves in the gastrointestinal tract. In: JOHNSON L. R. (ed.) Physiology of the Gastrointestinal Tract. New York: Raven Press, 1981. p. 197-241.

GABELLA, G. The number of neurons in the small intestine of mice, guinea-pigs and sheep. Neuroscience, v.22, n.2, p.737-752, 1987. Available from: <https://reader.elsevier.com/reader/sd/pii/ S0165183800001272? token $=020802863$ D1C7CD2D57BD26105 FF663DC1CB96F6C3DB6BC5E68C61E8EED12FA0C03A531 
97003B39F0210D5285D0B2238>. Accessed: Jul. 15, 2019. doi: $10.1016 / 0306-4522(87) 90369-1$

GÓIS, M. B. et al. Morphoquantitative study of Rattus norvegicus submucosal plexus by different neuronal evidentiation histochemical techniques. International Journal of morphology, v.34, n.4, p.1487-1493, 2016. Available from: $<$ http://www.intjmorphol.com/wp-content/uploads/2017/01/ art 50 344.pdf $>$. Accessed: Jul. 15, 2019. doi: 10.4067/S0717$950 \overline{2} 2016000400050$.

HANSEN, M. B. The enteric nervous system I: Organisation and classification. Pharmacology \& Toxicology, v.92, n.3, p.105113, 2003. Available from: <https://onlinelibrary.wiley.com/doi/ epdf/10.1034/j.1600-0773.2003.t01-1-920301.x>. Accessed: Jul. 15, 2019. doi: 10.1034/j.1600-0773.2003.t01-1-920301.x.

IRWIN, D. A. The anatomy of Auerbach's plexus. American Journal of Anatomy, v.49, n.1, p.141-166, 1931. Available from: $<$ https://anatomypubs.onlinelibrary.wiley.com/doi/abs/10.1002/ aja.1000490106>. Accessed: Jul. 15, 2019. doi: 10.1002/ aja.1000490106.

KANTAS, D. et al. The effect of a natural feed additive (Macleaya cordata), containing sanguinarine, on the performance and health status of weaning pigs. Animal Science Journal, v.86, n.1, p.92 98, 2015. Available from: <https://onlinelibrary.wiley.com/doi/ epdf/10.1111/asj.12240>. Accessed: Jul. 15, 2019. doi: 10.1111/ asj. 12240 .

KHADEM, A. et al. Growth promotion in broilers by both oxytetracycline and Macleaya cordata extract is based on their antiinflammatory properties. British Journal of Nutrition, v.12, n.7, p.1110-1118, 2014. Available from: <https://www.cambridge.org/ core/services/aop-cambridge-core/content/view/9FCE196B16DD 67373CCB4C0D77C3A9C8/S0007114514001871a.pdf/growth promotion in broilers by both oxytetracycline and macleaya cordata_extract_is_based_on_their_antiinflammatory_properties. pdf>. Accessed: Jul. 15, 2019. doi: 10.1017/S0007114514001871.

KOSINA, P. et al. Phytochemical and antimicrobial characterization of Macleaya cordata herb. Fitoterapia, v.81, n.8, p.1006-1012, 2004. Available from: <https://reader.elsevier.com/reader/sd/pii/ S0367326X10001504? token $=8$ F429247D0916B3349098FD2BE AF69D477949FACD65E8E90BF86A8CC255EB3A894AACB56 160A51B76C17BAEB86ED30F1>. Accessed: Jul. 15, 2019. doi: 10.1016/j.fitote.2010.06.020.

LANGLEY, J. The autonomic nervous system, Part I Cambridge: W. Heffer, 1921. 80p.

LI, Z. S. et al. Nitric oxide synthase in neurons of the gastrointestinal tract of an avian species, Coturnix coturnix. Journal of Anatomy, v.184, n.2, p.261-272, 1994. Available from: <https://www.ncbi. nlm.nih.gov/pmc/articles/PMC1259987/pdf/janat00139-0050. pdf $>$. Accessed: Jul. 15, 2019.

LIU, G. et al. Macleaya cordata extract decreased diarrhea score and enhanced intestinal barrier function in growing piglets. BioMed Research International, v.2016, p.1-7, 2016. Available from: $<$ http://downloads.hindawi.com/journals/bmri/2016/1069585. pdf $>$. Accessed: Jul. 15, 2019. doi: 10.1155/2016/1069585.

MIZUTA, Y. et al. Nitrergic regulation of colonic transit in rats. American Journal of Physiology, v.277, n.2, p.G275-G279, 1999. Available from: < https://journals.physiology.org/doi/pdf/10.1152/
ajpgi.1999.277.2.G275>. Accessed: Jul. 15, 2019. doi: 10.1152/ ajpgi.1999.277.2.G275

MURAKAMI, A. E.;ARIKI, J. Produção de codornas japonesas. Jaboticabal: FUNESP, 1998. v.1, 79 p.

OLIVEIRA, J. P. Avaliação de óleos essenciais, extratos vegetais e óleos funcionais em dietas de frangos de corte. 2012. 65 f. Dissertação (Mestrado em Fisiologia) - Setor de Ciências Biológicas, Universidade Federal do Paraná

OTUTUMI, L. K. et al. Effect of the addition of probiotic on performance, carcass yield and crude protein nutritional requirements of meat quails. Revista Brasileira de Zootecnia, v.38, n.2, p.299-306, 2009. Available from: <http://www.scielo.br/ pdf/rbz/v38n2/a12v38n2>. Accessed: Jul. 15, 2019. doi: 10.1590/ S1516-35982009000200012.

PASTORE, S. M. et al. Panorama da coturnicultura no Brasil Revista Eletrônica Nutritime, v.9, n.6, p.2041 - 2049, 2012. Available from: $<$ https://www.nutritime.com.br/arquivos_internos/ artigos $/ 180 \% 20 \quad$ Panorama $\% 20 \mathrm{da} \% 20$ coturnicultura .pdf $>$. Accessed: Jul. 15, 2019

PATRÍCIO, L. A. M. M. A importância da qualidade intestinal no desempenho de frangos de corte. 2016. Available from: $<$ http://ruralpecuaria.com.br/tecnologia-e-manejo/avicultura/ importancia-da-qualidade-intestinal-no-desempenho-de-frangosde-corte.html>. Accessed: Jul. 15, 2019.

PREVIATO DO AMARAL, P. F. G. et al. Salmonella Heidelberg reduces nitrergic neurons in the myenteric plexus of the duodenum of broilers. African Journal of Microbiology Research, v.11, n.33, p.1315-1320, 2017. Available from: $<$ https://academicjournals.org/ journal/AJMR/article-full-text-pdf/CEC976265872>. Accessed: Jul. 15, 2019. doi: 10.5897/AJMR2017.8593.

QU, Z. D. et al. Immunohistochemical analysis of neuron types in the mouse small intestine. Cell and Tissue Research, v.334, n.2, p.147-161, 2008. Available from: <https://link.springer.com/ content/pdf/10.1007/s00441-008-0684-7.pdf>. Accessed: Jul. 15, 2019. doi: 10.1007/s00441-008-0684-7.

ROSTAGNO, H. S. et al. Tabelas brasileiras para aves e suínos: composição de alimentos e exigências nutricionais. 4. ed. Viçosa: Departamento de Zootecnia, 2017.488p.

SANDERS, K. M.; WARD, S. M. Nitric oxide as a mediator of nonadrenergic noncholinergic neurotransmission. American Journal of Physiology, v.262, n.3, p.G379-G392, 1992. Available from: <https://journals.physiology.org/doi/pdf/10.1152/ ajpgi.1992.262.3.G379>. Accessed: Jul. 15, 2019. doi: 10.1152/ ajpgi.1992.262.3.G379.

SANGROVIT ${ }^{\circledR}$ ED. Eltville: Phytobiotics GmbH, 2019. Ficha Técnica. 2 p.

SANT'ANA, D. M. G. et al. Morphological and quantitative study of the myenteric plexus of the ascending colon of rats subjected to proteic desnutrition. Arquivos de Neuropsiquiatria, v.55, p.687-695, 1997. Available from: <https://www.scielo.br/pdf/ anp/v55n4/03.pdf $>$. Accessed: Jul. 15, 2019. doi: 10.1590/S0004282X1997000500003.

SANT'ANA, D. M. G. et al. Characterization of the myenteric neuronal population and subpopulation of the duodenum of adult 
wistar rat fed with hypoproteic chow. Annals of the Brazilian Academy of Sciences, v.84, n.3, p.799-806, 2012. Available from: $<$ https://www.scielo.br/pdf/aabc/v84n3/aop5212.pdf $>$. Accessed: Jul. 15, 2019. doi: 10.1590/S0001-37652012005000050.

SCHEMANN, M. Control of gastrointestinal mobility by the "gut brain - The enteric nervous system. Journal of Pediatric Gastroenterology and Nutrition, v.41, n.1, p.4-6, 2005. Available from: $\quad<$ https://journals.lww.com/jpgn/fulltext/2005/09001/ control_of_gastrointestinal_motility_by_the_gut.3.asp $\mathrm{x}>$. Accessed: Jul. 15, 2019. doi: 10.1097/01.scs.0000180285.51365.55.

SCHERER-SINGLER, U. et al. Demonstration of unique population of neurons with NADPH-diaphorase histochemistry. The Journal of Neuroscience Methods, v.9, n.3, p.229-234, 1983. Available from: $<$ https://reader.elsevier.com/reader/sd/pii/0165027083900857?token $=$ B303607324228096CA036FC8E7C41D5C415C0D94E49A553A 91B4B9EE9DF283F190C68FE872573400DB6625CD45825BC4>. Accessed: Jul. 15, 2019. doi: 10.1016/0165-0270(83)90085-7.

SERENINI, G. F. et al. Quantification of the neurons of myenteric plexus of the bat molossus rufus. Pesquisa Veterinária Brasileira, v.40, n.6, p.493-500, 2020. Available from: $<$ https://www.scielo. br/pdf/pvb/v40n6/1678-5150-pvb-40-06-493.pdf>. Accessed: Jul. 15, 2019. doi: 10.1590/1678-5150-PVB-6381.

SILVA, A. F. et al. Quail production as an alternative to improve income to small farmers. Arquivo Brasileiro de Medicina Veterinária e Zootecnia, v.70, n.3, p.913-920, 2018. Available from: $\quad<$ http://www.scielo.br/pdf/abmvz/v70n3/0102-0935abmvz-70-03-00913.pdf>. Accessed: Jul. 15, 2019. doi: $10.1590 / 1678-4162-10065$.
ŠIMANEK, V. et al. Quaternary benzoiciphenanthridine alkaloids - Biological activities. In: SCHNEIDER, M. P. Chemical Probes in Biology. Dordrecht: Kluwer Academic Publishers, 2003. p.245-254.

STABILLE, S. R. et al. General characteristics of the myenteric neurons of the médium intestinal segment of Piaractus mesopotamicus (Holmberg, 1887) (Teleostei:Serrasalmidae). Arquivos de Ciências da Saúde da UNIPAR, v. 6, n.1, p.3-9, 2002. Available from: $<$ https://revistas.unipar.br/index.php/saude/ article/view/1143/1005>. Accessed: Jul. 15, 2019. doi: 10.25110/ arqsaude.v6i1.2002.1143.

TAKEUCHI, $\mathrm{T}$. et al. Roles of $\mathrm{M}_{2}$ and $\mathrm{M}_{4}$ muscarinic receptors in regulating acetylcholine release from myenteric neurons of mouse ileum. Journal of Physiology, v.93, n.5, p.2841-2848, 2005. Available from: <https://journals.physiology.org/doi/pdf/10.1152/ jn.00986.2004>. Accessed: Jul. 15, 2019. doi: 10.1152/ jn.00986.2004.

YANG, P. et al. Quantitative changes of nitrergic neurons during postnatal development of chicken myenteric plexus. Journal of Zhejiang University - Science B (Biomed \& Biotechnol), v.4, n.10, p.886-895, 2013. Available from: $<$ https://link.springer.com/ content/pdf/10.1631/jzus.B1300005.pdf>. Accessed: Jul. 15, 2019. doi: 10.1631/jzus.B1300005.

ZDAŘILOVÁ, A. et al. Kvartérní isochinolinové alkaloidy sanguinarin a chelerythrin. Účinky in vitro a in vivo. Chemické Listy, v.100, n.1, p.30-41, 2006. Available from: <http:// ww.chemicke-listy.cz/docs/full/2006 01 30-41.pdf>. Accessed: Jul. 15, 2019 